\title{
Low-inductance snubber arrays for high-power, high-bandwidth switch-mode amplifiers
}

\author{
Daniel J. Rogers, Padmavathi Lakshmanan \\ Institute of Energy, School of Engineering, Cardiff University, Cardiff, U.K. \\ e-mail: RogersDJ@cardiff.ac.uk, LakshmananP2@cardiff.ac.uk.
}

\begin{abstract}
This paper presents a low inductance snubber design incorporating a damped DC bus capacitance and multiple $R C+R C D$ cells arranged in two arrays. The design suppresses transient over-voltage peaks seen at the switching transitions in hard-switched, high-frequency switch-mode circuits which are created by an unavoidable interaction between circuit parasitic inductances, IGBT turn-off current slopes and free-wheeling diode reverse recovery currents. The array arrangement allows the use of small surface-mount, ultrafast diodes by enforcing current sharing between many devices. An industrial application example is presented where the snubber design enables an increase in DC bus voltage from $200 \mathrm{~V}$ to $400 \mathrm{~V}$ when using $600 \mathrm{~V}$ Si IGBTs operated at a switching frequency of $75 \mathrm{kHz}$. Simulation results are presented and compared to experimental measurements to illustrate the operating principle and effectiveness of the array design.

Index Terms-IGBT modules, snubbers, parasitic inductances, switching transients, switched mode power supplies, surface mounting, $\mathrm{RC}$ circuits.
\end{abstract}

\section{INTRODUCTION}

$\mathrm{S}$ ome applications of switch-mode power electronic converters are constrained to operate at very high switching frequencies beyond that which is normally considered optimal for power conversion or machine-drive applications. In these applications, the inevitably higher semiconductor device switching losses are accepted in order to obtain other benefits resulting from high switching frequencies, for example high signal bandwidth or a minimum passive component size [1], [2]. The upper limit on switching frequency depends typically on one of two considerations: Hard-switched circuits suffer significant switching loss which scales linearly with switching frequency, therefore, as switching frequency is increased, the thermal dissipation capability of the semiconductor devices may be exceeded, or some minimum acceptable system efficiency figure will be reached. Alternatively, and especially for switch-mode power electronic circuits rated above a few kilowatts and targeting switching frequencies $>50 \mathrm{kHz}$, circuit parasitic inductances can create large over-voltage stress across the switching devices [3]. This is because high switching frequencies imply high $\mathrm{V}=\mathrm{L} . \mathrm{di} / \mathrm{dt}$ switching transitions, and this must be factored into the device voltage headroom to ensure circuit reliability. Parasitic inductances may be minimized through careful bus bar design [4], [5] and the use of low ESL DC bus capacitors but can never be entirely eliminated. The simple engineering solutions of employing devices with a higher voltage rating and/or of deliberately slowing down the switching process to limit di/dt both tend to increase losses. This is because higher voltage devices incur increased conduction losses (due to a higher on-state voltage drop) and artificially slow switching speeds increase switching losses. In addition, higher voltage devices are more expensive and may require a specialized power module design. In conclusion, designs intended to operate at very high switching frequencies, parasitic inductances can become a major limiting factor preventing economic increases in power output.

Application examples that require operation at very high switching frequencies are the high-bandwidth high-power industrial amplifiers used in vibration testing systems and current control systems for MRI scanners. Such systems must typically be capable of providing a flat frequency response from DC to $5 \mathrm{kHz}$, at an output of around $20 \mathrm{kVA}$. Switch-mode designs are preferred due to their high efficiency, however, to satisfy THD limits and accurately reproduce the reference waveform, switching frequencies approaching $100 \mathrm{kHz}$ are typically employed which is at the edge of that achievable using current standard large silicon IGBT devices. At the switching transitions, current transfer rates of over $1000 \mathrm{~A} / \mu \mathrm{s}$ is common. This is necessary to reduce IGBT switching losses by limiting the time the IGBTs spend in the partially-on state. However, the resultant voltage transients produced across circuit parasitic inductance can necessitate a very significant DC bus voltage derating to stay within the safe operating area of all devices. Voltage stress is often most severe across the opposing freewheel diode at IGBT turn-on. This is due to the $\mathrm{di} / \mathrm{dt}$ of the decaying reverse recovery current just after voltage is recovered across the diode. This so-called 'snap' of the diode can produce a large voltage across the DC bus interconnection inductance which constructively adds to the static DC bus voltage. If large enough, this voltage will cause the power devices to break down and result in an uncontrolled short circuit current and the destruction of the diode and IGBT.

Snubbers are a class of circuit that are used to control and reduce over-voltages seen by a switching device at turn-on and turn-off. Careful application of snubber circuits can effectively increase the maximum usable current and voltage of the IGBTs, particularly in hard-switched circuits. Snubbers can 


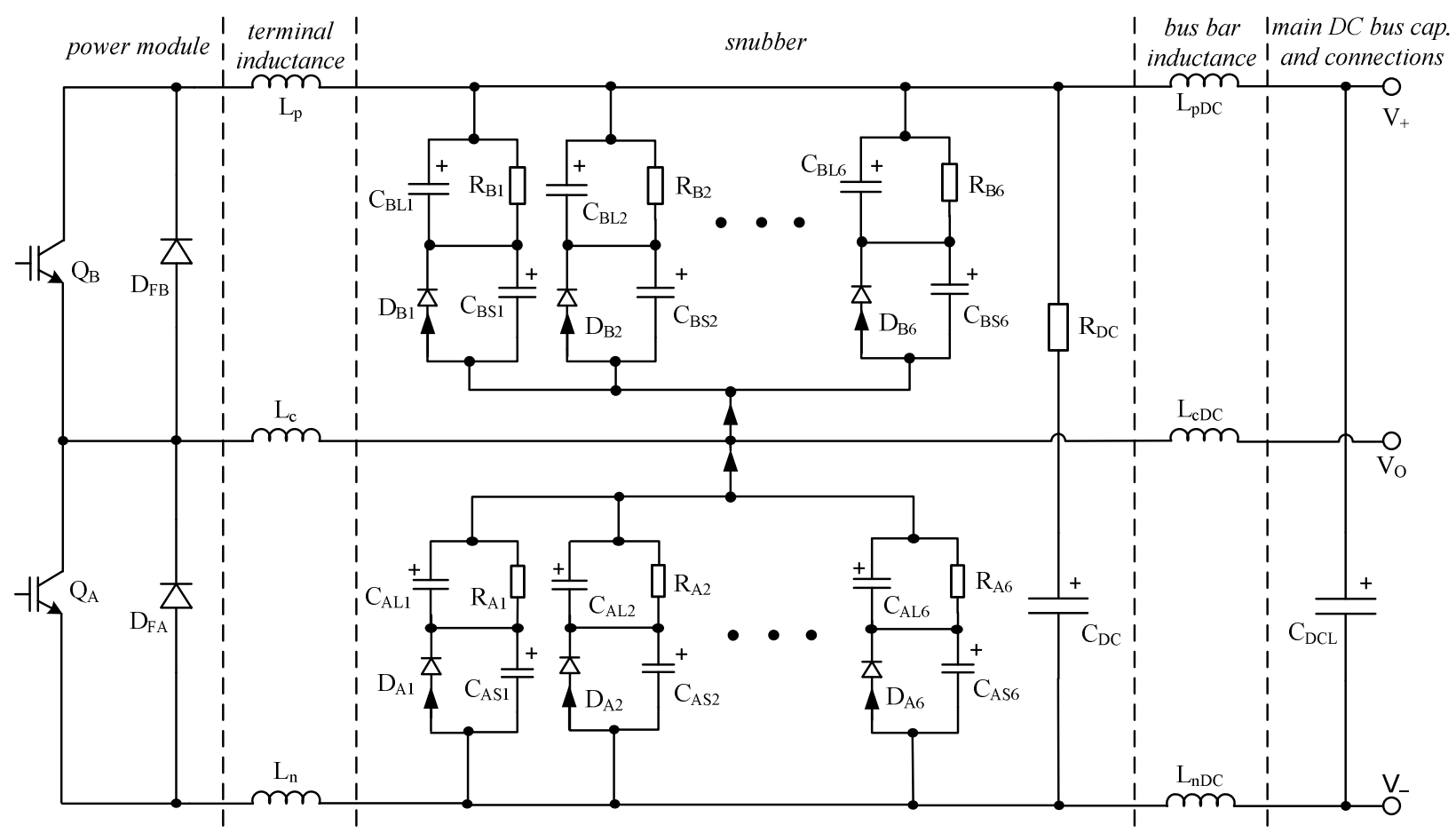

Fig. 1. Schematic diagram of proposed array-based snubber connected to a power module showing major parasitic inductances

allow the use of a lower device voltage rating than would otherwise be possible, or allow a retrofit opportunity to increase the operating voltage of an existing design. Snubbers also tend to limit the occurrence of sustained high-frequency current and voltage oscillations at the switching transitions, resulting in reduced EMI potential [6].

Snubber circuits can be classified as active or passive types. Active snubber circuits [7] need additional auxiliary switch and complex control mechanisms to perform the snubber action. Passive snubber circuits [8] use resistors, capacitors and diodes only and require no external control mechanism. Passive snubbers are often preferred due to their simple and reliable operation. The use of diode clamps and basic series and shunt snubber action are described in [9] and the design methods for selecting optimum component values in $\mathrm{RC}$ (Resistor-Capacitor) snubber circuits with an aim to minimize the device peak voltage and power losses are discussed in [10]. RCD (Resistor-Capacitor-Diode) snubbers with snubber capacitor energy recovery schemes are reported in [11], [12] and two different configurations of RCD snubbers for high current IGBTs are described in [13]. The work [14] reports a dynamic current sharing snubber for parallel connected IGBTs in high power applications.

\section{A LOW-INDUCTANCE SNUBBER ARRAY DESIGN}

The snubber circuit proposed in this paper and its intended placement between the supply and power module is shown in Fig. 1. The corresponding physical layout of the snubber and its mounting on the power module is shown in Fig. 2. The snubber design is a combination of a damped DC bus capacitance, a passive RC snubber and a passive RCD clamp. The RC snubbers and RCD clamps are referred to as snubber arrays composed of cells in which the corresponding cell components are labeled with the subscript suffix 1-6 in Fig. 1.

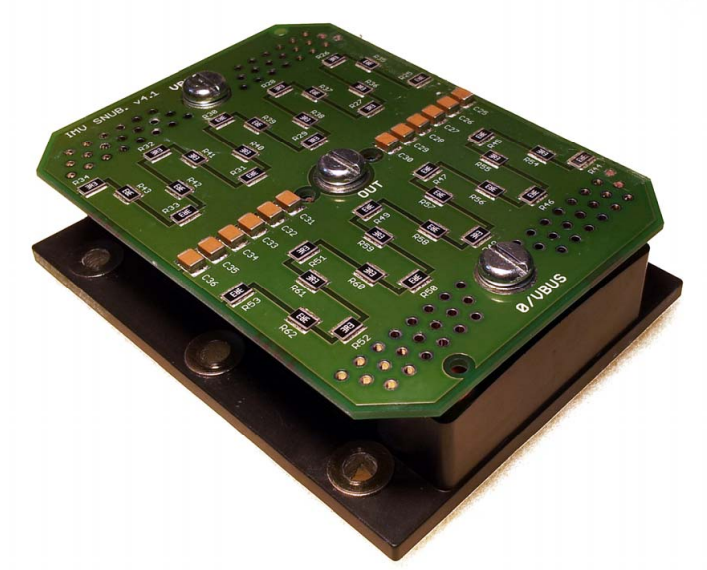

Fig. 2.a Array-based snubber mounted on the power module. The top of the snubber PCB is visible, showing $\mathrm{R}_{\mathrm{DC}}$ and $\mathrm{C}_{\mathrm{DC}}$



Fig. 2.b Bottom side of the array-based snubber PCB showing two $\mathrm{RC}+\mathrm{RCD}$ snubber arrays composed of six cells each 


\section{A. PCB layout and component selection}

A snubber must be of very low inductance itself in order to have a maximum effect in reducing peak voltages generated by other circuit parasitic inductances [15], [16]. This may be illustrated by noting that an inductance of only $50 \mathrm{nH}$ will cause a voltage drop of $125 \mathrm{~V}$ when exposed to a $40 \mathrm{~ns}, 100 \mathrm{~A}$ switching edge. Given that a standard TO220 package lead has an inductance of about $10 \mathrm{nH}$ alone, it is clear that a snubber composed of multiple leaded components is fundamentally limited in the clamping effect it can achieve. To obtain the lowest possible inductance and maximum clamping effect, a snubber should employ surface mount devices (SMD) and be mounted as close as physically possible to the semiconductor devices to be protected. Assuming a typical IGBT power module which is cooled on one side with electrical connections made on the opposing side, a snubber constructed on a PCB of the same footprint as the module and using the same connection pattern allows a close connection directly to the module, thus minimizing the parasitic inductance appearing between the snubber and the IGBT and providing maximum voltage clamping efficacy. This type of arrangement is shown in Fig 2.a.

The use of multiple physically small didoes in the RCD clamps is advantageous for four reasons. Firstly, small surface mount diodes in the 3-10A range are commonly available and are low-cost due to their small silicon area and high manufacturing yields. Secondly, the effective 'spreading' of a total silicon area over many parallel paths leads to a reduction in overall interconnection inductance below that achievable for a single large-area device. Thirdly, the spreading effect is also advantageous in terms of the thermal design as system heat output is dissipated over a larger heatsink area. Fourthly, physically small devices can be expected to have good internal current density uniformity when compared to larger devices. This may be expected to improve overall robustness as long as current sharing between diodes can be ensured. However, it cannot be assumed that direct-connected paralleled diodes will share current equally due to variations between individual diode die and in path resistances and inductances. For this reason the snubber array arrangement of Fig. 1 and Fig. 2.b is introduced to enforce current sharing between several separate diode paths. Current sharing between cells of the array is discussed in Section III.B.

\section{B. Damped DC bus capacitance}

High power switch-mode circuits normally employ a lowinductance laminated bus bar design connecting the power module to a large electrolytic or film capacitor bank. However, the physical separation between the power module and the main DC bus capacitors produce an unavoidable parasitic inductance of the order $70 \mathrm{nH}$ (this is represented by $\mathrm{L}_{\text {pdc }}$ and $\mathrm{L}_{\text {ndc }}$ in Fig. 1). This is enough inductance to cause significant over voltages and ringing at turn-on and turn-off for many cycles when no snubber is in place. To counter this effect, a small localized $\mathrm{DC}$ bus capacitance $\mathrm{C}_{\mathrm{DC}}$ may be incorporated on one side of the snubber PCB, along with a damping resistance $\mathrm{R}_{\mathrm{DC}}$, which should be tuned to provide critical damping of the resulting resonant LC circuit now formed by the loop composed of the main DC bus capacitance $\left(\mathrm{C}_{\mathrm{DCL}}\right.$ in Fig. 1) and $\mathrm{L}_{\mathrm{pdc}}, \mathrm{L}_{\mathrm{ndc}}$ and $\mathrm{C}_{\mathrm{DC}}$. The parasitic inductance $\left(\mathrm{L}_{\mathrm{p}}\right.$ and $\mathrm{L}_{\mathrm{n}}$ in Fig. 1) present between the power module and the snubber should be minimized to ensure effectiveness of this additional DC bus capacitance. The internal parasitic inductance of the snubber may be minimized by constructing the bulk capacitance from many surface mount devices connected in parallel as shown in Fig. 2.a. The peak power dissipation of the damping resistance can be very high (approaching the system VA rating) and, especially for high switching frequencies, the average power dissipation will be significant. Again, the use of many SMD resistors in parallel will keep parasitic inductance low and will also provide a large surface area for heat removal, keeping component temperatures within limits.

\section{C. $R C+R C D$ snubber cells}

The voltage oscillations seen at the center terminal of the half-bridge at turn-on and turn-off can be controlled by an RC snubber or RCD clamp [13]. For a given capacitance value, the RCD clamp produces much lower power losses when compared to the $\mathrm{RC}$ snubber because the snubber capacitance is not fully charged and discharged on every switching cycle. At high switching frequencies the power dissipation of an RC snubber quickly becomes prohibitive. The additional IGBT stresses caused by the discharge current of the $\mathrm{RC}$ snubber at switch-on are also unwelcome. However, the RC snubber has the advantage of virtually instantaneous operation because there is no turn-on delay associated with a diode (as there is in the RCD clamp). This is particularly relevant when considering very high switching frequencies because the turn on delay of the snubber diode can approach that of the current commutation time, making the RCD clamp ineffective at controlling peak voltages.

A parallel combination of a small-value RC snubber and an RCD clamp can serve to combine the advantages of both types, allowing to the control of the initial overvoltage without incurring excessive power losses [17]. Effectively, the RC snubber provides the initial current path while the RCD clamp transitions into conduction to provide the main current path for the remainder of the commutation time. In the circuit of Fig. 1, the $\mathrm{RC}$ snubber is formed by the series connection of $\mathrm{C}_{\mathrm{xSn}}$ and $\mathrm{C}_{\mathrm{xLn}}$, where $\mathrm{x}=\mathrm{A}$ or $\mathrm{B}$ (depending on placement with respect to the lower or upper device of the power module) and $1 \leq \mathrm{n} \leq 6$ (corresponding to the cell number). The capacitances are sized such that $\mathrm{C}_{\mathrm{xLn}}>>\mathrm{C}_{\mathrm{xSn}}$ and so the effective capacitance of each cell of the RC snubber can be approximated as $\mathrm{C}_{\mathrm{xSn}}$. The RCD clamp is formed by the series connection of $D_{x n}$ and $C_{x L n}$. The charge transferred to $\mathrm{C}_{\mathrm{xLn}}$ and $\mathrm{C}_{\mathrm{xSn}}$ during a switching transition is discharged by $\mathrm{R}_{\mathrm{xn}}$ during the time before the next transition.

\section{Simulation RESUltS}

In order to study the operation of the proposed snubber a simplified version of the circuit of Fig. 1 was simulated using the PLECS block set for MATLAB [18]. The PLECS block set uses a behavioral model of IGBTs and diodes (including reverse recovery) which overcomes some of the limitations of standard SPICE models when used in power electronic applications [19]. The simplified circuit used in the simulation to analyse the turn-on and turn-off transients is shown in 


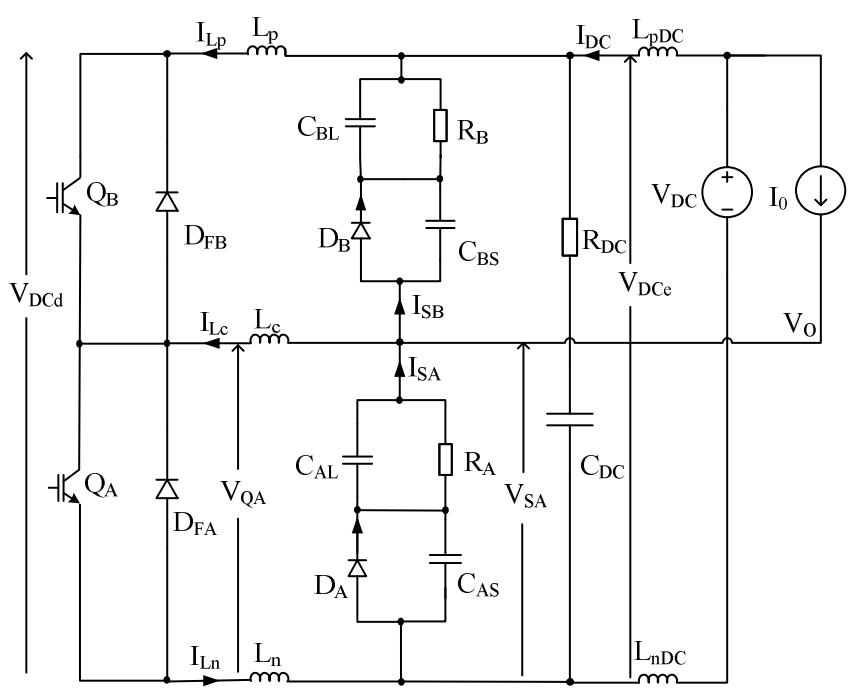

Fig. 3. Simplified scaled model used to analyse turn-on and turn-off transients TABLE I

SIMULATION MODEL PARAMETERS

\begin{tabular}{|c|c||c|c|}
\hline \multicolumn{2}{|c||}{$\begin{array}{c}\text { Full six-cell circuit } \\
\text { (Fig. 1 and Fig. 2) }\end{array}$} & \multicolumn{2}{c|}{$\begin{array}{c}\text { Scaled single-cell circuit } \\
\text { (Fig. 3) }\end{array}$} \\
\hline Component & Value & Component & Value \\
\hline $\mathrm{V}_{\mathrm{DC}}$ & $400 \mathrm{~V}$ & $\mathrm{~V}_{\mathrm{DC}}$ & $400 \mathrm{~V}$ \\
\hline $\mathrm{I}_{0}$ & $100 \mathrm{~A}$ & $\mathrm{I}_{0}$ & $16.7 \mathrm{~A}$ \\
\hline $\mathrm{f}_{\mathrm{s}}$ & $75 \mathrm{kHz}$ & $\mathrm{f}_{\mathrm{s}}$ & $75 \mathrm{kHz}$ \\
\hline $\mathrm{R}_{\mathrm{DC}}$ & $0.347 \Omega$ & $\mathrm{R}_{\mathrm{DC}}$ & $1.96 \Omega$ \\
\hline $\mathrm{C}_{\mathrm{DC}}$ & $1.2 \mu \mathrm{F}$ & $\mathrm{C}_{\mathrm{DC}}$ & $200 \mathrm{nF}$ \\
\hline $\mathrm{L}_{\mathrm{pDC}}$ and $\mathrm{L}_{\mathrm{nDC}}$ & $35 \mathrm{nH}$ & $\mathrm{L}_{\mathrm{pDC}}$ and $\mathrm{L}_{\mathrm{nDC}}$ & $200 \mathrm{nH}$ \\
\hline $\mathrm{L}_{\mathrm{p}} \mathrm{L}_{\mathrm{n}}$ and $\mathrm{L}_{\mathrm{c}}$ & $15 \mathrm{nH}$ & $\mathrm{L}_{\mathrm{p}} \mathrm{L}_{\mathrm{n}}$ and $\mathrm{L}_{\mathrm{c}}$ & $80 \mathrm{nH}$ \\
\hline $\mathrm{R}_{\mathrm{Al}}-\mathrm{R}_{\mathrm{A} 6}$ and $\mathrm{R}_{\mathrm{Bl}}-\mathrm{R}_{\mathrm{B} 6}$ & $5 \Omega$ & $\mathrm{R}_{\mathrm{A}}$ and $\mathrm{R}_{\mathrm{B}}$ & $5 \Omega$ \\
\hline $\mathrm{C}_{\mathrm{ASI}}-\mathrm{C}_{\mathrm{AS} 6}$ and $\mathrm{C}_{\mathrm{BS1}}-\mathrm{C}_{\mathrm{BS} 6}$ & $1.5 \mathrm{nF}$ & $\mathrm{C}_{\mathrm{AS}}$ and $\mathrm{C}_{\mathrm{BS}}$ & $1.5 \mathrm{nF}$ \\
\hline $\mathrm{C}_{\mathrm{AL} 1}-\mathrm{C}_{\mathrm{AL} 6}$ and $\mathrm{C}_{\mathrm{BL} 1}-\mathrm{C}_{\mathrm{BL} 6}$ & $100 \mathrm{nF}$ & $\mathrm{C}_{\mathrm{AL}}$ and $\mathrm{C}_{\mathrm{BL}}$ & $100 \mathrm{nF}$ \\
\hline
\end{tabular}

Fig. 3. The simplified model was scaled to include only a single snubber cell for the upper and lower devices of the power module. It carries one sixth of the load current $I_{0}$ and the other passive and parasitic component values are scaled proportionally $\left(\mathrm{V}_{\mathrm{DC}}\right.$ remains $\left.400 \mathrm{~V}\right)$.

The values of the parasitic inductances were chosen based on experimental measurements (see Section V) and with reference to [15], [16], which list parasitic inductance values typical of commercial IGBT power modules. Component values used in the simulation model are listed in Table I. An inductive load was assumed and modeled as a constant current source flowing into the terminal $V_{O}$ from the positive supply. A gate drive signal with a switching frequency of $75 \mathrm{kHz}$ was applied to the lower IGBT of the module and the upper IGBT $\mathrm{Q}_{B}$ held off. When the lower IGBT $\mathrm{Q}_{\mathrm{A}}$ is off, the load current freewheels through the upper free-wheeling diode $\mathrm{D}_{\mathrm{FB}}$.

\section{A. Snubber operation during turn-on and turn-off}

The expanded transition waveforms of the simulated turn-on and turn-off transients are shown in Fig. 4. A step by step discussion of snubber operation with reference to Fig. 4 now follows. Note that $S_{A}$ refers to the lower RC+RCD snubber array $\left(D_{A}, C_{A L}, R_{A}, C_{A S}\right)$ and $S_{B}$ refers to the upper snubber array $\left(D_{B}, C_{B L}, R_{B}, C_{B S}\right)$

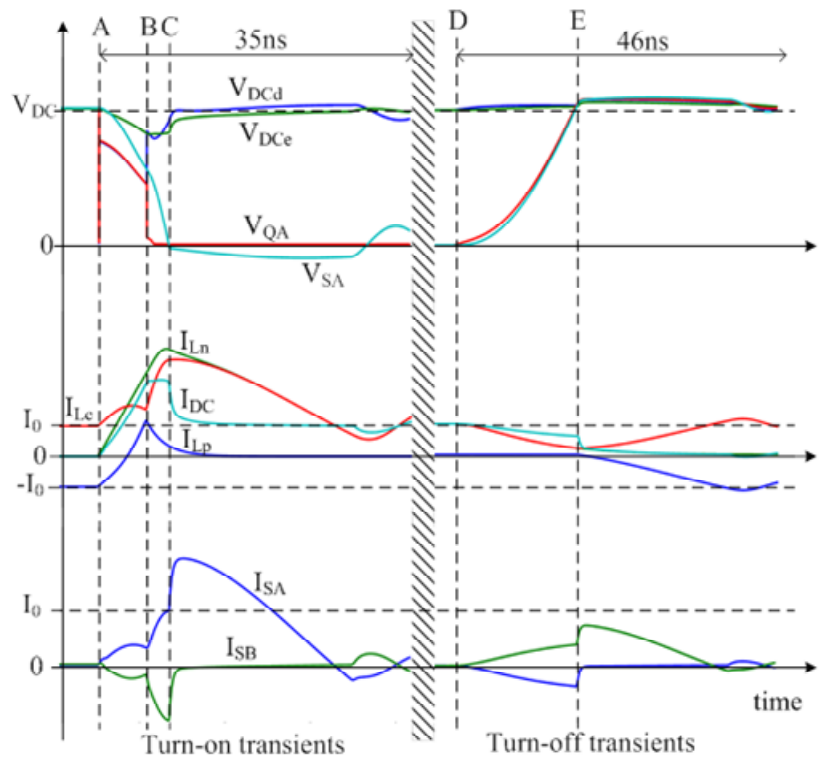

Fig. 4. Turn-on and turn-off transients (on/off state refers to $Q_{A}$ ).

A: The gate pulse turns $\mathrm{Q}_{\mathrm{A}}$ on. Current increases approximately linearly in $\mathrm{Q}_{\mathrm{A}}$ at the rate of $\mathrm{dI}_{\mathrm{QA}} / \mathrm{dt}$ and so the voltage across $\mathrm{Q}_{\mathrm{A}}$ falls by $\left(\mathrm{dI}_{\mathrm{QA}} / \mathrm{dt}\right) .\left(\mathrm{L}_{\mathrm{n}}+\mathrm{L}_{\mathrm{p}}\right)$.

A to $B: \mathrm{D}_{\mathrm{FB}}$ is conducting and so the voltage across $\mathrm{L}_{\mathrm{c}}$ is equal to $\left(\mathrm{dI}_{\mathrm{QA}} / \mathrm{dt}\right) \cdot \mathrm{L}_{\mathrm{p}}$, causing a current to build in $\mathrm{L}_{\mathrm{c}}$. This current flows in the snubber $\left(\mathrm{I}_{\mathrm{SA}}\right.$ and $\left.\mathrm{I}_{\mathrm{SB}}\right)$ and causes the voltage $\mathrm{V}_{\mathrm{SA}}$ to fall.

$B$ : Once $\mathrm{D}_{\mathrm{FB}}$ reaches peak reverse recovery current, it appears as a current source with a decaying reverse recovery current and the voltage across $\mathrm{Q}_{\mathrm{A}}$ rapidly collapses to near-zero.

$B$ to $C$ : $\mathrm{C}_{\mathrm{AS}}$ discharges and $\mathrm{C}_{\mathrm{BS}}$ charges through $\mathrm{Q}_{\mathrm{A}}$ which builds a further current in $\mathrm{L}_{\mathrm{c}}$.

$C$ : Once the voltage across $\mathrm{C}_{\mathrm{AS}}$ falls to zero, $\mathrm{D}_{\mathrm{A}}$ is forward biased and $\mathrm{C}_{\mathrm{AL}}$ appears as a virtual short circuit (as it is large).

$C$ onwards: Current in $\mathrm{S}_{\mathrm{B}}$ rapidly transfers to $\mathrm{S}_{\mathrm{A}}$ as $\mathrm{C}_{\mathrm{AL}} \gg \mathrm{C}_{\mathrm{BS}}$. The reverse recovery current of $\mathrm{D}_{\mathrm{FB}}$ finishes decaying. The current in $L_{n}$ and $L_{c}$ decays to the steady state value $\mathrm{I}_{0}$ via $\mathrm{S}_{\mathrm{A}}$ (some oscillations occur as stored energy is dissipated in $R_{A}$ and $R_{B}$ ).

$D$ : Gate pulse turns $\mathrm{Q}_{\mathrm{A}}$ off. Current falls in $\mathrm{Q}_{\mathrm{A}}$. As $\mathrm{D}_{\mathrm{FB}}$ is reverse biased it does not conduct.

$D$ to $E$ : Current $\mathrm{I}_{0}-\mathrm{I}_{\mathrm{QA}}$ flows in $\mathrm{S}_{\mathrm{A}}$ and $\mathrm{S}_{\mathrm{B}}$ capacitors, causing the voltage $\mathrm{V}_{\mathrm{SA}}$ to rise.

$E$ : The voltages across $\mathrm{D}_{\mathrm{FB}}$ and $\mathrm{S}_{\mathrm{B}}$ fall to near-zero, $\mathrm{D}_{\mathrm{FB}}$ and $\mathrm{D}_{\mathrm{B}}$ are forward biased.

$E$ onwards: Current in $\mathrm{S}_{\mathrm{A}}$ rapidly transfers to $\mathrm{S}_{\mathrm{B}}$ as $\mathrm{C}_{\mathrm{BL}} \gg \mathrm{C}_{\mathrm{AS}}$. Current in $\mathrm{D}_{\mathrm{FB}}$ builds as result of the small positive voltage across $S_{B}$. The current in $L_{p}$ and $L_{c}$ decays to steady state value $I_{0}$ via $S_{A}$ (some oscillations occur as stored energy is dissipated in $\mathrm{R}_{\mathrm{A}}$ and $\mathrm{R}_{\mathrm{B}}$ ).

\section{B. Current sharing between snubber array cells}

In the preceding discussion, at the instant at which the snubber diode $\mathrm{D}_{\mathrm{A}}$ becomes forward biased, current initially flows in $\mathrm{C}_{\mathrm{AS}}$ and $\mathrm{C}_{\mathrm{AL}}$. As $\mathrm{C}_{\mathrm{AS}}<\mathrm{C}_{\mathrm{AL}}$, the majority of the 


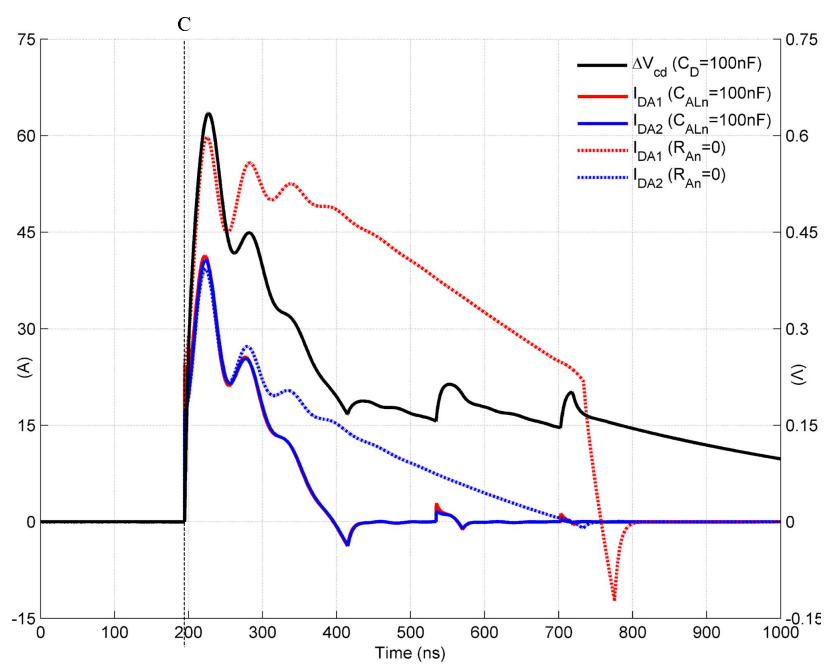

Fig. 5. Current sharing at turn-on between snubber cells for diodes with different V-I characteristics

voltage is built across $C_{A S}\left(R_{A}\right.$ is large and so has little effect during the commutation process). The voltage across $\mathrm{C}_{\mathrm{AS}}$ forward biases $\mathrm{D}_{\mathrm{A}}$ which begins to conduct after undergoing forward recovery. The forward voltage and delay depends on the conduction characteristics of the diode and these parameters may vary from device to device. In the six-cell design (Fig. 1), the purpose of $\mathrm{C}_{\mathrm{xLn}}$ is to dynamically balance the currents flowing in the diodes by building a small opposing voltage proportional to the share of current flowing in each cell. In this way, cells that take a large share of the current will build a larger opposing voltage across $C_{x L n}$ which will tend to reduce the current flowing in this cell. Choosing a smaller value of $C_{x L n}$ will increase the strength of the balancing effect, however it is desirable to use as large a value as possible for $\mathrm{C}_{\mathrm{xLn}}$ in order to minimize the voltage increase above the corresponding clamp voltage.

The current distribution effect for the non-uniform diode characteristics among the lower snubber array diodes $\left(\mathrm{D}_{\mathrm{A1}}-\mathrm{D}_{\mathrm{A} 6}\right)$ was investigated using a full simulation model which included six cells as shown in Fig. 1. The diodes $\mathrm{D}_{\mathrm{A} 2}-\mathrm{D}_{\mathrm{A} 5}$ were modeled with a forward voltage of $\mathrm{V}_{\mathrm{F}}=1.3 \mathrm{~V}$ and a forward resistance of $R_{F}=20 \mathrm{~m} \Omega$. Diode $D_{A 1}$ was modified to $\mathrm{V}_{\mathrm{F}}=1.1 \mathrm{~V}$ and $\mathrm{R}_{\mathrm{F}}=10 \mathrm{~m} \Omega$. The current sharing effect is demonstrated in Fig. 5 showing two different cases, one representing the designed value of $\mathrm{C}_{\mathrm{ALn}}=100 \mathrm{nF}$ and the other case where $\mathrm{R}_{\mathrm{An}}=0$ (effectively $\mathrm{C}_{\mathrm{ALn}}=\infty$ ). The differential cell capacitor voltage is used to illustrate the current sharing arrangement between the cells with mismatched diodes $\left(\Delta \mathrm{V}_{\mathrm{cd}}=\mathrm{V}_{\mathrm{CAL2} 2}-\mathrm{V}_{\mathrm{CAL1}}\right)$. For the diode currents $\mathrm{I}_{\mathrm{DA} 1}$ and $\mathrm{I}_{\mathrm{DA} 2}$ corresponding to the case of $\mathrm{C}_{\mathrm{ALn}}=100 \mathrm{nF}$, it can be seen that $\Delta \mathrm{V}_{\mathrm{cd}}$ rapidly builds to approximately $0.63 \mathrm{~V}$ to compensate for the different $\mathrm{V}-\mathrm{I}$ characteristics of the two diodes. As a result of this, the snubber current is shared almost equally between the mismatched diodes. For the case where $\mathrm{R}_{\mathrm{An}}=0$ the current sharing is not equal due to the uncompensated differences in diode V-I characteristics, in this case $\mathrm{D}_{\mathrm{A} 1}$ experiences approximately twice the currents of $\mathrm{DA}_{2-6}$ which implies this device would be likely to fail early unless the rating of the system was reduced to take imbalances into account. In
TABLE II

LOSS ANALYSIS BY SIMULATION

\begin{tabular}{|c|c|c|c|c|c|}
\hline \multicolumn{2}{|c|}{ Components } & \multicolumn{2}{|c|}{ Without Snubber } & \multicolumn{2}{|c|}{ With Snubber } \\
\hline $\mathrm{O}_{4}$ & Turn-on & $\begin{array}{l}\text { Average } \\
\text { (W) } \\
2.90\end{array}$ & $\begin{array}{l}\begin{array}{c}\text { Peak } \\
(\mathrm{kW})\end{array} \\
1.42\end{array}$ & $\begin{array}{c}\begin{array}{c}\text { Average } \\
(\mathrm{W})\end{array} \\
70.5\end{array}$ & $\begin{array}{l}\begin{array}{l}\text { Peak } \\
(\mathrm{kW})\end{array} \\
31.4\end{array}$ \\
\hline & Turn-off & 395 & 42.4 & 130 & 9.10 \\
\hline & Conduction & 150 & & 150 & \\
\hline & Total & 548 & & 351 & \\
\hline \multirow[t]{3}{*}{$\mathrm{D}_{\mathrm{FB}}$} & Turn-on & 92.9 & 80.7 & 65.1 & 37.4 \\
\hline & Conduction & 103 & & 103 & \\
\hline & Total & 196 & & 168 & \\
\hline \multirow[t]{6}{*}{ Snubber } & $\mathrm{R}_{\mathrm{DC}}$ & & & 79.3 & 19.2 \\
\hline & $\mathrm{R}_{\mathrm{A}}$ & & & 50.6 & 1.85 \\
\hline & $\mathrm{R}_{\mathrm{B}}$ & & & 9.48 & 0.31 \\
\hline & $\mathrm{D}_{\mathrm{A}}$ & & & 6.86 & 1.77 \\
\hline & $\mathrm{D}_{\mathrm{B}}$ & & & 1.83 & 0.31 \\
\hline & Total & & & 148 & \\
\hline \multicolumn{2}{|c|}{ All components total } & 744 & & 667 & \\
\hline
\end{tabular}

conclusion, the array-cell balancing arrangement insures that all diodes conduct a nearly-equal share of the snubber current allowing the snubber to be operated at a total current near to the sum of the forward current ratings of the individual diodes.

\section{Circuit losses}

A circuit model of Fig. 1 was simulated with a DC bus voltage of $400 \mathrm{~V}$ and a load current of $100 \mathrm{~A}$. The peak and average power losses were calculated using the simulated voltage and current waveforms of the power devices and snubber components. The simulation was repeated for the same power circuit operated without a snubber and the resulting power losses are compared in Table II.

Without the snubber, the turn-on losses in $\mathrm{Q}_{\mathrm{A}}$ are remarkably low because during the turn-on period a large fraction of the DC bus voltage is dropped across the DC bus parasitic inductance (note that it is this same inductance which causes the large over-voltage peak seen during the reverse recovery of the freewheeling diode). When the snubber is present, the apparent DC bus inductance is reduced and so this effect is less pronounced and the losses are higher. In addition, the peak turn-on current carried by $\mathrm{Q}_{\mathrm{A}}$ is roughly doubled due to the charging and discharging currents of the upper and lower snubber arrays respectively (see Fig. 4. B-C). The losses in the freewheeling diode $\mathrm{D}_{\mathrm{FB}}$ are lower when the snubber is present because the voltage across the diode is better controlled (i.e. lower) and so the charge transferred during the reverse recovery of the diode dissipates less energy.

At turn-off, in the case without the snubber, the voltage across $\mathrm{Q}_{\mathrm{A}}$ rises instantaneously before the current in $\mathrm{Q}_{\mathrm{A}}$ begins to fall. With the snubber present, the voltage across $\mathrm{Q}_{\mathrm{A}}$ rises slowly during the period in which the current rises leading to reduction in the energy dissipated by two thirds. In both cases the switching loss associated with $\mathrm{D}_{\mathrm{FB}}$ is very small (the forward recovery voltage is below $20 \mathrm{~V}$ ).

Fundamentally, the RC snubbers and RCD clamps are dissipative. $\mathrm{R}_{\mathrm{DC}}$ provides damping of the $\mathrm{LC}$ circuit formed by the $\mathrm{DC}$ bus inductance $\mathrm{L}_{\mathrm{pDC}}, \mathrm{L}_{\mathrm{nDC}}, \mathrm{C}_{\mathrm{DCL}}$ and $\mathrm{C}_{\mathrm{DC}}$ and therefore the majority of the energy stored in the DC bus inductances is dissipated in $\mathrm{R}_{\mathrm{DC}}$ at turn-on and turn-off giving rise to a significant power dissipation in $\mathrm{R}_{\mathrm{DC}}$. Moreover, at $\mathrm{Q}_{\mathrm{A}}$ turn-on, the $\mathrm{D}_{\mathrm{FB}}$ reverse recovery current flows in the $\mathrm{DC}$ bus resulting in additional energy dissipated in $\mathrm{R}_{\mathrm{DC}}$. Dissipation in $\mathrm{R}_{\mathrm{A}}$ and 
$\mathrm{R}_{\mathrm{B}}$ is due to the charge transferred to $\mathrm{C}_{\mathrm{AS}}, \mathrm{C}_{\mathrm{AL}}, \mathrm{C}_{\mathrm{BS}}$ and $\mathrm{C}_{\mathrm{BL}}$ as a result of the voltage clamping action of the snubber. The clamp energy is dissipated slowly in $\mathrm{R}_{\mathrm{A}}$ and $\mathrm{R}_{\mathrm{B}}$ after the turnon and turn-off events have occurred. The charge transfer is greatest in the snubber arrays connected across the conducting IGBT and so for the direction of current flow studied here, $\mathrm{R}_{\mathrm{A}}$ dissipates significantly more power than $R_{B}$. Snubber diode losses are small in comparison to losses elsewhere due to the very low average forward current experienced by these devices.

Although there is significant power dissipation in the snubber components, the total loss figures show that overall losses with the snubber are about $10 \%$ lower than without the snubber, principally due to the large reduction in $\mathrm{Q}_{\mathrm{A}}$ turn-off losses. The overall power loss occurring in the power module (IGBT plus diode) is reduced by about $30 \%$. In addition, IGBT peak power stress is reduced by about $25 \%$ and diode peak power stress is reduced by about $50 \%$ which may be advantageous in terms of device reliability. It is clear from the power dissipation figures that the snubber will require thermal management solution itself (the snubber accounts for $22 \%$ of overall dissipation). Although overall losses are slightly lower and therefore the complete thermal management solution overall may be of lower capacity, the additional complexity required to manage the snubber dissipation is potentially costly.

\section{EXPERIMENTAL RESULTS}

\section{A. Experimental snubber construction details}

The physical arrangement of both sides of the snubber PCB and its attachment to the power module is shown in Fig. 2. In the experimental set-up, $\mathrm{C}_{\mathrm{DC}}$ was composed of 12 parallel connected $500 \mathrm{~V}$ X7R dielectric ceramic capacitors in an 1812 SMD package of $100 \mathrm{nF}$ each $\left(1.2 \mu \mathrm{F}\right.$ in total). $\mathrm{R}_{\mathrm{DC}}$ was composed of $38,3.3 \Omega$ thick film resistors in a 1218 SMD package, connected as two series banks of 19 resistors in parallel $(0.347 \Omega$ in total).

The RC+RCD snubber arrays were composed of six cells for each device (i.e. 12 cells for each half-bridge power module). The cell diodes are STTH3R06S, SMC package, rated at $600 \mathrm{~V}, 3 \mathrm{~A}$ with $\mathrm{t}_{\mathrm{rr}}=35 \mathrm{~ns}$. $\mathrm{R}_{\mathrm{xn}}$ is constructed from two $10 \Omega, 1218$ package resistors connected in parallel. Values for other components are given in Table I.

The large number of individual components serves two purposes, it reduces the effective inductance (roughly proportional to $1 / \mathrm{N}$, where $\mathrm{N}$ is the number of paralleled devices), but also limits the current density and therefore the power loss density to within acceptable limits. This is particularly important in the case of $\mathrm{R}_{\mathrm{DC}}$ which suffers both high average losses and high peak losses.

\section{B. Comparison with simulation}

Fig. 6 shows a comparison of experimental and simulation results for the operation at a DC bus voltage of $400 \mathrm{~V}$ load current of $100 \mathrm{~A}$. Note that the voltages measured correspond to the 'external' voltages at the terminals of the snubber, i.e. $\mathrm{V}_{\mathrm{SA}}$ and $\mathrm{V}_{\mathrm{DCe}}$ in Fig. 3. There is generally good agreement between the voltages waveforms, with the exception of pulse
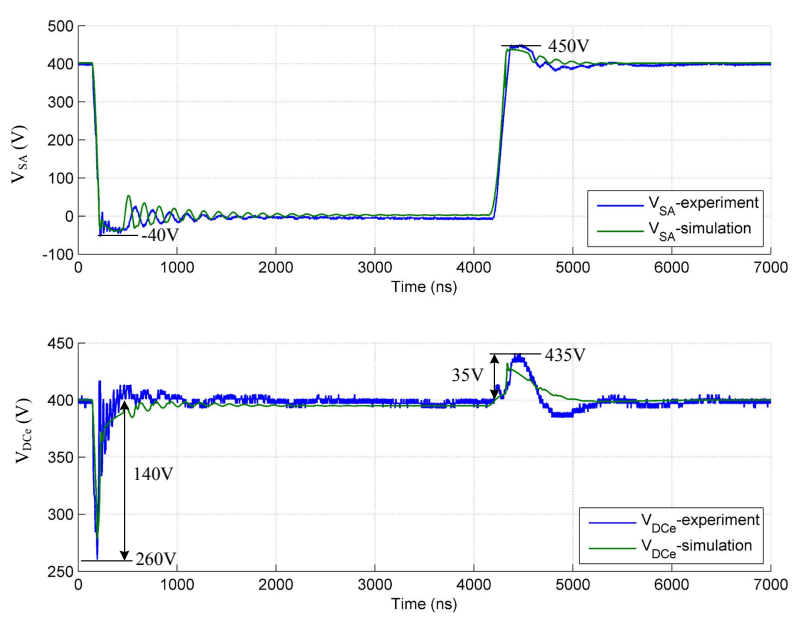

Fig. 6. Comparison of simulation and experimental results for the array snubber $(400 \mathrm{~V} / 100 \mathrm{~A})$

shape of the DC link voltage at turn off, although the peak voltage amplitudes are similar.

\section{Application example}

An industrial H-bridge amplifier using two half-bridge IGBT modules serves as an application example for the proposed snubber design. This amplifier was originally designed for operation using a $200 \mathrm{~V}$ dc nominal bus voltage, delivering 100 A rms continuously and 200 A peak for $100 \mathrm{~ms}$. The IGBT power modules used in the amplifier are half-bridge Microsemi CMIMLGF100A60G rated at $600 \mathrm{~V}$ and $300 \mathrm{~A}$ which contain integrated driver circuitry (this power module is visible in Fig. 2.a). Each IGBT in the module is composed of ten IGBT dies (Infineon SGP30N60) and each diode is composed of five diode dies (Microsemi APT60D60B, fast recovery epitaxial type). External power connection is by three M6 screws to a laminated bus bar arrangement connecting the modules to two $3300 \mathrm{uF}$ electrolytic DC bus capacitors.

The modules are operated interleaved at a switching frequency of $75 \mathrm{kHz}$ in order to provide the required overall amplifier bandwidth (effective switching frequency of 150 $\mathrm{kHz}$ ). This switching frequency requires very fast switching transitions (about $40 \mathrm{~ns}$ ) to minimize switching loss and provide a faithful reproduction of the target waveform. The resulting large di/dt values produce correspondingly very large peak over-voltages when the devices are operated without a snubber. In order to limit peak voltages and meet EMI design requirements, the original amplifier design included an RCD clamp employing leaded (through-hole) components to damp radio-frequency oscillations that were otherwise observed to persist for several tens of cycles at each switching edge. Although somewhat effective at damping these oscillations, initial peak device voltages of $340 \mathrm{~V}$ were observed at the terminal of the device when delivering 100 A load current from a $200 \mathrm{Vdc}$ supply. Internal device voltages are likely to be $10-20 \%$ higher due to additional internal parasitic inductances, but these voltages cannot be measured routinely due to the module encapsulation. When increasing the DC bus voltage to $350 \mathrm{Vdc}$, intermittent failure of the IGBT modules was observed. For long-term reliable operation, a DC bus 



Fig. 7. Comparison of experimental results for three different cases (200 V/100 A). TH: Through Hole, SMA: Surface Mount Array
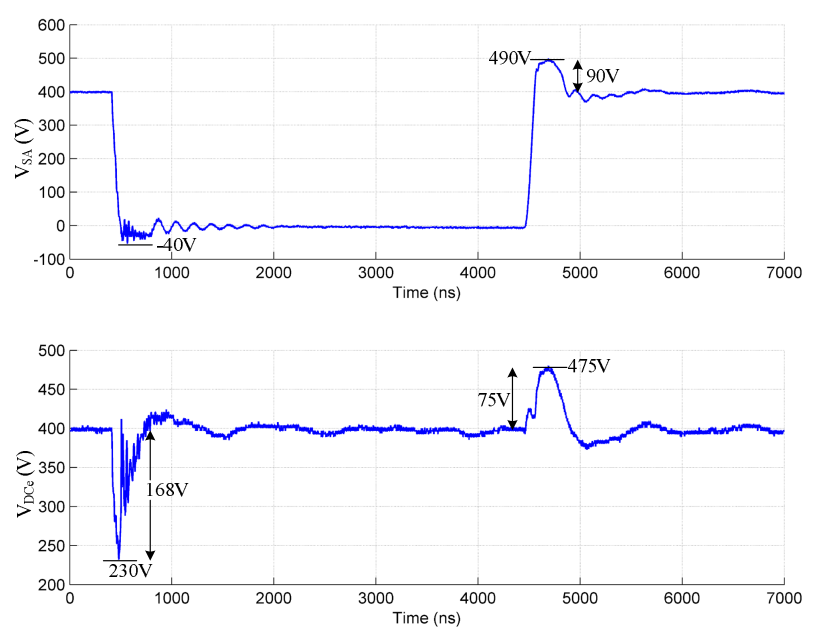

Fig. 8. Experimental results for overload conditions using the SMA snubber voltage of about $300 \mathrm{Vdc}$ proved to be the upper limit for these IGBT modules operated with the leaded RCD clamp. This is a typical example of the large derating necessary to ensure safe operation of a semiconductor device operating at very high switching speeds (a $600 \mathrm{~V}$ device used in a $200 \mathrm{Vdc}$ bus equates to a voltage derating of $67 \%$ ).

A design challenge was set to extend the amplifier supply voltage to $400 \mathrm{Vdc}$ at the same current ratings, allowing a $100 \%$ increase in the rated power output of system. This was to be achieved without changing the design of the power module or power circuit design but instead by improving on the existing snubber design so that the peak overvoltage experienced by the module was kept below the rating of $600 \mathrm{~V}$.

\section{Comparison with alternative circuit options}

To investigate the comparative effectiveness of the proposed snubber design, additional experiments were performed for three different cases, the first corresponding to operation with no snubber, the second to the existing snubber design based on Through Hole (TH) components and the third case to the proposed low inductance array snubber.

A comparison using a DC bus voltage of $200 \mathrm{~V}$ with a load current of $100 \mathrm{~A}$ is shown in Fig. 7. In the 'without snubber' case, the bridge output voltage $\left(\mathrm{V}_{\mathrm{SA}}\right)$ has very large overvoltages and ringing at both switch on and switch off for many cycles due to the interaction of the power device and circuit parasitic inductances. The presence of a large DC bus parasitic inductance can be observed indirectly via the large voltage drop at the power module terminals at turn-on. An increase in DC bus voltage is not possible as the peak device voltage is over $550 \mathrm{~V}$ (the rated voltage of the power module is $600 \mathrm{~V}$ ). The through-hole snubber suppresses the peak over-voltage but still shows oscillations for many cycles, largely as a result of the inherent inductances of the leaded components used in its construction. This is particularly evident at the instant of freewheeling diode recovery at $\mathrm{Q}_{\mathrm{A}}$ turn-on where a large peak voltage of about $40 \%$ of the DC bus voltage is developed. It would be problematic to increase DC bus voltage beyond approximately $300 \mathrm{~V}$ due to the magnitude of the over-voltage developed. In the SMA snubber case, the localized DC bus capacitance and action of the RC+RCD snubber is effective at suppressing the over voltage peak at turn-on to less than $10 \%$ of the DC bus voltage.

In addition, the clamping effect of the RCD clamp and the damping effect of $\mathrm{R}_{\mathrm{DC}}$ are effective in suppressing oscillations, resulting in an improved EMI performance.

A further experiment was conducted to observe the effect of the snubber when the system is subject to transient overload conditions. In this case, the load current was increased to $200 \mathrm{~A}$ at a DC bus voltage of $400 \mathrm{~V}$, representing a $100 \%$ overload condition. The results are shown in Fig. 8 where it can be seen that although there is a significant voltage drop across the power module terminals at turn-on, the overvoltage at turn-off is controlled to within $25 \%$ of the DC bus voltage, ensuring the power module continues to operate within its voltage rating.

\section{CONCLUSION}

The operation of a low-inductance combined RC+RCD snubber has been explored through simulation and verified experimentally. A localized damped DC bus capacitance is used to suppress DC bus over-voltage peaks in combination with an array design concept which enforces current sharing between multiple small SMD diodes, allowing the low parasitic inductance and fast switching performance of these devices to be fully utilized for fast voltage clamping action.

In a practical retro-fit industrial application, the snubber design has been shown to be highly effective at suppressing transient over-voltages and sustained oscillations that otherwise occur due to the interaction of fast switching transitions and circuit parasitic inductances. The design is specifically suited to applications requiring very high switching frequencies and therefore subject to fast switching transitions. As an example of what may be achieved, when applied to an existing high-bandwidth amplifier the snubber has allowed the DC bus voltage to be increased from $200 \mathrm{~V}$ to $400 \mathrm{~V}$ when using a $600 \mathrm{~V}$ power module, resulting in a 
doubling in amplifier power handling capability subject only to the relatively low additional cost of the snubber.

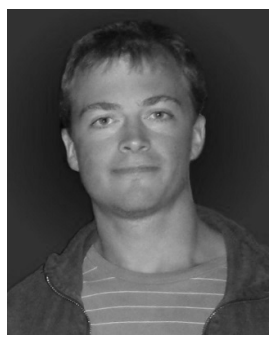

Daniel J. Rogers (M'09) received the M.Eng. and $\mathrm{Ph} . \mathrm{D}$. degrees in electrical and electronic engineering from Imperial College London, London, U.K., in 2007 and 2011 respectively. Currently, he is a Lecturer in the Institute of Energy, Cardiff University, Cardiff, U.K. He conducts research in collaboration with industry and is involved with the development of highperformance power electronic systems for a variety of companies. He is an investigator on several EPSRC and EU research projects in the areas of power electronics, HVDC and grid-scale energy storage. His research interests include the use of medium- and large-scale power-electronic systems to create flexible electrical networks capable of taking advantage of a diverse range of generation technologies, and the subsequent control challenges this produces.

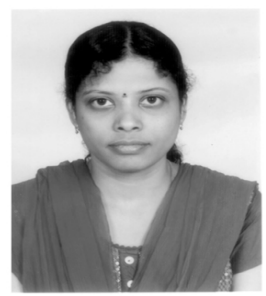

Padmavathi Lakshmanan received the Ph.D. degree in electrical and electronic engineering from Indian Institute of Technology Madras, India, in 2011. Currently, she is a Research assistant in the Institute of Energy, Cardiff University, Cardiff, U.K. Her research interests include power electronics and renewable energy.

\section{REFERENCES}

1. Abou-Alfotouh, A.M., Radun, A., Chang, H.R., and C. Winterhalter.: 'A 1-MHz hard-switched silicon carbide dc-dc converter', IEEE Trans. Power Electron., 2006, 21, (4), pp. 880-889.

2. Eberle, W., Zhang, Z., Liu, Y.F., and P.C. Sen.: "A current source gate driver achieving switching loss savings and gate energy recovery at 1-MHz', IEEE Trans. Power Electron., 2008, 23, (2), pp.678-691.

3. Wang, J., Chung, H.S., and Li, R.T.: 'Characterization and experimental assessment of the effects of parasitic elements on the MOSFET switching performance', IEEE Trans. Power Electron., 2013, 28, (1), pp.573-590.

4. Caponet, M.C., Profumo, F., De Doncker, R.W., and Tenconi, A.: 'Low stray inductance bus bar design and construction for good EMC performance in power electronic circuits', IEEE Trans. Power Electron., 2002, 17, (2), pp. 225 - 231.

5. Lounis, Z., Rasoanarivo, I., and Davat, B.: 'Minimization of wiring inductance in high power IGBT inverter', IEEE Trans. Power Delivery., 2000, 15, (2), pp. 551 - 555.

6. Yaisom, C.U., Khanngern, W., and Nitta, S.: 'The study and analysis of the conducted EMI suppression on power MOSFET using passive snubber circuits', in Proc. ELMAGC, 2002, pp. 561-564.

7. Jung, J.H., Ahmed, S.: 'Flyback converter with novel active clamp control and secondary side post regulator for low standby power consumption under high-efficiency operation', IET Power Electron., 2011, 4, (9), pp. 1058-1067.

8. Mohammadi, M., Adib, E., Farzanehfard, H.: 'Lossless passive snubber for double ended flyback converter with passive clamp circuit', IET Power Electron., 2014, 7, (2), pp. 245-250.

9. McMurray, W.: 'Selection of snubbers and clamps to optimize the design of transistor switching converters', IEEE Trans. Ind. Appl., 1980, 16, (4), pp. 513-523.

10. McMurray, W.: 'Optimum snubbers for power semiconductors', IEEE Trans. Ind. Appl., 1972, 8, (5), pp. 593-600.

11. Peng, F.Z., Su, G.J., and Tolbert, L.M.: 'A Passive Soft Switching Snubber for PWM Inverters', IEEE Trans. Power Electron., 2004 19, (2), pp. 363-370.

12. Lim, T.C., Williams, B.W., Finney, S.J, Zhang, H.B., and Croser, C.: 'Energy recovery snubber circuit for a $\mathrm{dc}-\mathrm{dc}$ push -pull converter', IET Power Electron., 2012, 5, (6), pp. 863-872.
13. Chokhawala, R.S., and Sobhani, S.: 'Switching voltage transient protection schemes for high-current IGBT modules', IEEE Trans. Ind. Appl., 1997, 33, (6), pp. 1601-1610.

14. He, J., and Jacobs, M.E.: 'Non-dissipative dynamic current sharing snubber for parallel connected IGBTs in high power boost converters', in Proc APEC, 1999, pp. 1105-1111.

15. Xing, K., Lee, F.C., and Boroyevich, D.: 'Extraction of parasitics within wire-bond IGBT modules', in Proc. APEC, 1994 pp. 497-503.

16. Li, S., Tolbert, L.M., Wang, F., and Peng, F.Z.: 'P-cell and N-cell based IGBT module: layout design, parasitic extraction and experimental verification', in Proc. APEC, 2011, pp.372-378.

17. Hren, A., Korelic, J., and Milanovic, M.: 'RC-RCD Clamp Circuit for Ringing Losses Reduction in a Flyback Converter', IEEE Trans. Circuits and Systems II: Express Briefs, 2006, 53, (5), pp. 369-373.

18. JAllmeling, J.H., and Hammer, W.P.: 'PLECS- Piece-wise Linear Electrical Circuit Simulation for Simulink', in Proc. PEDS'99, vol. 1, pp. 355-360.

19. Massmoudi, N., M'bairi, D., B. Allard, B., and Morel, H.: 'On the validity of the standard SPICE model of the diode for simulation in power electronics,' IEEE Trans. Ind Electron., 2001, 48, (4), pp. 864-867.

20. Mohan, N., Undeland, T.M., and W. P. Robbins, 'Power Electronics: Converters, Applications and Design'. New York: Wiley, 1995.

21. Cai, C., Jun, P.X., Yu, C., and K. Yong, K.: 'The loss calculation of RCD snubber with forward and reverse recovery effects considerations', in Proc. ICPE \& ECCE, 2011, pp. 3005 - 3012. 